\title{
A Case of Syringocystadenoma Papilliferum of External Auditory Canal
}

\author{
Junhyuk Jang ${ }^{1}$ iD, Sung Yool Park ${ }^{1}$, , Ha Young Park ${ }^{2}$, and Kyung Wook Heo ${ }^{1}$ (iD \\ ${ }^{1}$ Departments of Otorhinolaryngology-Head and Neck Surgery, ${ }^{2}$ Pathology, Busan Paik Hospital, Inje University College of Medicine, \\ Busan, Korea
}

\section{외이도에 발생한 유두상 한선낭샘종 1예}

\author{
장준혁 ${ }^{1} \cdot$ 박성율 $^{1} \cdot$ 박하영 $^{2} \cdot$ 허경욱 $^{1}$ \\ 인제대학교 의과대학 부산백병원 이비인후-두경부외과학교실, ${ }^{1}$ 병리학교실 ${ }^{2}$
}

\author{
Received August 21, 2020 \\ Revised November 12, 2020 \\ Accepted November 19, 2020 \\ Address for correspondence \\ Kyung Wook Heo, MD, PhD \\ Department of Otorhinolaryngology- \\ Head and Neck Surgery, \\ Busan Paik Hospital, \\ Inje University, College of Medicine, \\ 75 Bokji-ro, Busanjin-gu, \\ Busan 47392, Korea \\ Tel $+82-51-890-6379$ \\ Fax +82-51-892-3831 \\ E-mail heokw96@daum.net
}

Ceruminous glands are specialized sudoriferous glands located in the external auditory canal (EAC). Tumors originating from these ceruminous glands are rare lesions of EAC; in particular, syringocystadenoma papilliferum (SCAP) is an extremely rare ceruminous glands neoplasm to occur in the EAC. Although it is rare, the association of SCAP with tubular apocrine adenoma in the background of nevus sebaceous on the body, extremities, and scalp is well documented. In this article, we report on a 60 -year-old male who presented a mass in EAC, which was surgically removed. The final diagnosis of SCAP was determined by histological analysis and the patient has been well without recurrence.

Korean J Otorhinolaryngol-Head Neck Surg 2021;64(6):444-7

Key Words Apocrine glands · External auditory canal · Pathology $\cdot$ Sweat gland adenoma.

\section{서 론}

이구선은 아포크린선의 변형된 형태로, 외이도 연골부 피부 의 가장 깊은 곳에 위치하며 이구를 생성한다. 이구선 기원의 종물은 매우 드물고 전체 외이도 종물의 $5 \%$ 정도를 차지하는 것으로 알려져 있다. ${ }^{1)}$ 이구선 종양은 1972년 Wetli 등이 4그 룹으로 분류한 이후 2그룹이 추가되어 세계보건기구(World Health Organization) 기준 6가지로 구분되는데, ${ }^{2)}$ 양성종양 으로는 이구선 선종(ceruminous adenoma), 이구선 다형선종 (ceruminous pleomorphic adenoma), 이구선 유두상 한선낭 샘종(ceruminous syringocystadenoma papilliferum, SCAP) 이 있고, 악성종양은 이구선암종(ceruminous adenocarcino$\mathrm{ma}$, 이구선 선양낭포암종(adenoid cystic carcinoma), 이구선

This is an Open Access article distributed under the terms of the Creative Commons Attribution Non-Commercial License (https://creativecommons.org/licenses/by-nc/4.0) which permits unrestricted non-commercial use, distribution, and reproduction in any medium, provided the original work is properly cited. 점액상피양암종(mucoepidermoid carcinoma)이 있다. 이들 중 이구선 선양낭포암종이 가장 흔한 것으로 알려져 있다.2)

$\mathrm{SCAP}$ 의 경우 두부와 안면부에서는 종종 발생하지만 외이 도에서는 매우 드문 것으로 알려져 있으며, 판(plaque), 구진 (papule) 또는 각화성 결절 등의 형태로 관찰되고 여러가지 피부 부속기 종양, 특히 피지선 모반과 동반되어 나타날 수 있 다. ${ }^{3,4)}$ 국내에서 외이도에 발생한 SCAP는 관상아포크린선종 (tubular apocrine adenoma, TAA)과 병발한 경우가 기존에 3예 보고된 바가 있으나 단독 발생한 증례는 보고된 바가 없 다. ${ }^{4-6)}$ 이에 저자들은 외이도에서 단독으로 발생한 SCAP를 치험하였기에 문헌 고찰과 함께 보고하는 바이다.

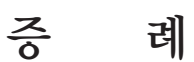

60세 남자 환자가 5년 전에 발견되어 점진적으로 크기가 증 가하는 우측 외이도 종물을 주소로 본원 외래에 내원하였다. 
귀질환의 병력이나 특이 가족력은 없으며, 난청, 이통, 이루 등 의 증상은 호소하지 않았다. 이경 소견상 우측 외이도 후벽에 서 기원하여 외이도를 막고 있는 매끈한 표면을 가진 종물이 관찰되었고, 종물은 $1 \mathrm{~cm}$ 가량의 직경으로 분비물은 없었다 (Fig. 1A). 그 외 부분의 외이도와 고막은 정상 소견이었다. 순음청력검사상 양측 정상 청력이었고(Fig. 1B), 뼈알고리즘 (bone algorithm) 전산화단층촬영(CT)상 우측 외이도를 막고 있는 연조직 음영의 종물 소견이었으며, 외이도 골 침범의 소 견은 없었고 중이 및 내이는 정상 소견이었다(Fig. $1 \mathrm{C}$ and D).

외이도 양성 종양의 의심하에 외래에서 침윤마취하에 절개 생검을 시행하였다. 병리소견상 낭성구조 내부에 입방 세포 (cuboidal cell)가 단두양 분비(decapitation secretion)를 이 루는 것이 관찰되었고, 주위로 근상피세포(myoepithelial cell) 가 유두상 돌기 형태로 둘러싸여 있어 이구선 혹은 아포크린 선에서 기원한 양성 종물로 판단되었으나 최종 병리진단은 내 릴 수 없었다.

부분 마취하에 경외이도 접근법을 시행했다. 종물이 외이
도 후벽에서 기원하는 부위와 외이도의 상하부위에 Octocaine $^{\circledR}(2 \%$ lidocaine +100000 epinephrine $)$ 을 주사하여 국 소마취를 시행한 다음 15 번 칼날로 피부절개를 시행하여 종 물의 피막을 노출시켰다. 미세가위와 박리기로 노출된 피막 을 따라 정상피부와 종물을 분리하여 $1.2 \times 0.9 \times 0.6 \mathrm{~cm}$ 크기 의 종물을 완전절제했다(Fig. 2A). 절제 조직의 병리 검사에서 두 겹 이상의 아포크린 상피를 가진 수많은 유두상 돌기 조 직과 유두상 돌기의 간질에 빽빽한 조직구 침윤이 관찰되어 $\mathrm{SCAP}$ 로 진단되었으며(Fig. 2B-D), 수술 3개월 뒤 외래에서 진찰 소견상 우측 외이도와 고막은 정상 소견이었다. 수술 후 2년째 재발 등 특이소견은 없이 외래 추적 관찰 중이다.

\section{고 찰}

피부부속기 종양은 모낭선, 에크린선, 아포크린선 등의 구 조물이 형태적으로 변화한 것이다. 아포크린선 유래의 종양 에는 한선종(hidradenoma), 한관종(syringoma), 원주종(cyl-
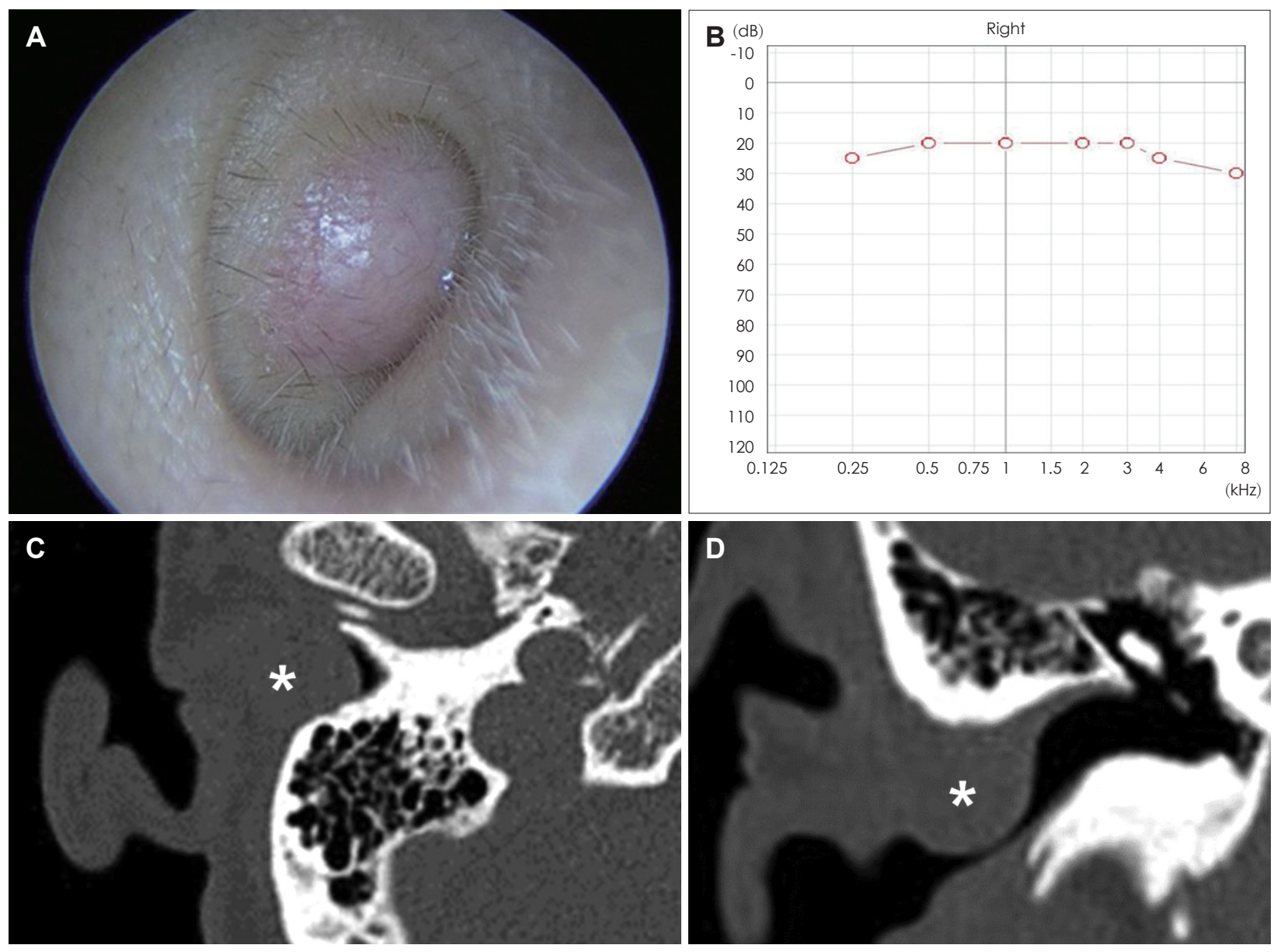

Fig. 1. Preoperative findings of the lesion. Right EAC is totally obstructed by a pinkish mass with covering skin arising from posterior wall (A). Pure tone audiogram reveals normal hearing in right ear with pure tone threshold of $23 \mathrm{~dB}(\mathrm{~B})$. Preoperative computed tomography scans of the temporal bone show homogenous protruded mass $\left(^{*}\right)$ arising from posterior wall of right EAC without evidence of invasion to the bony wall; axial image (C), coronal image (D). EAC: external auditory canal. 


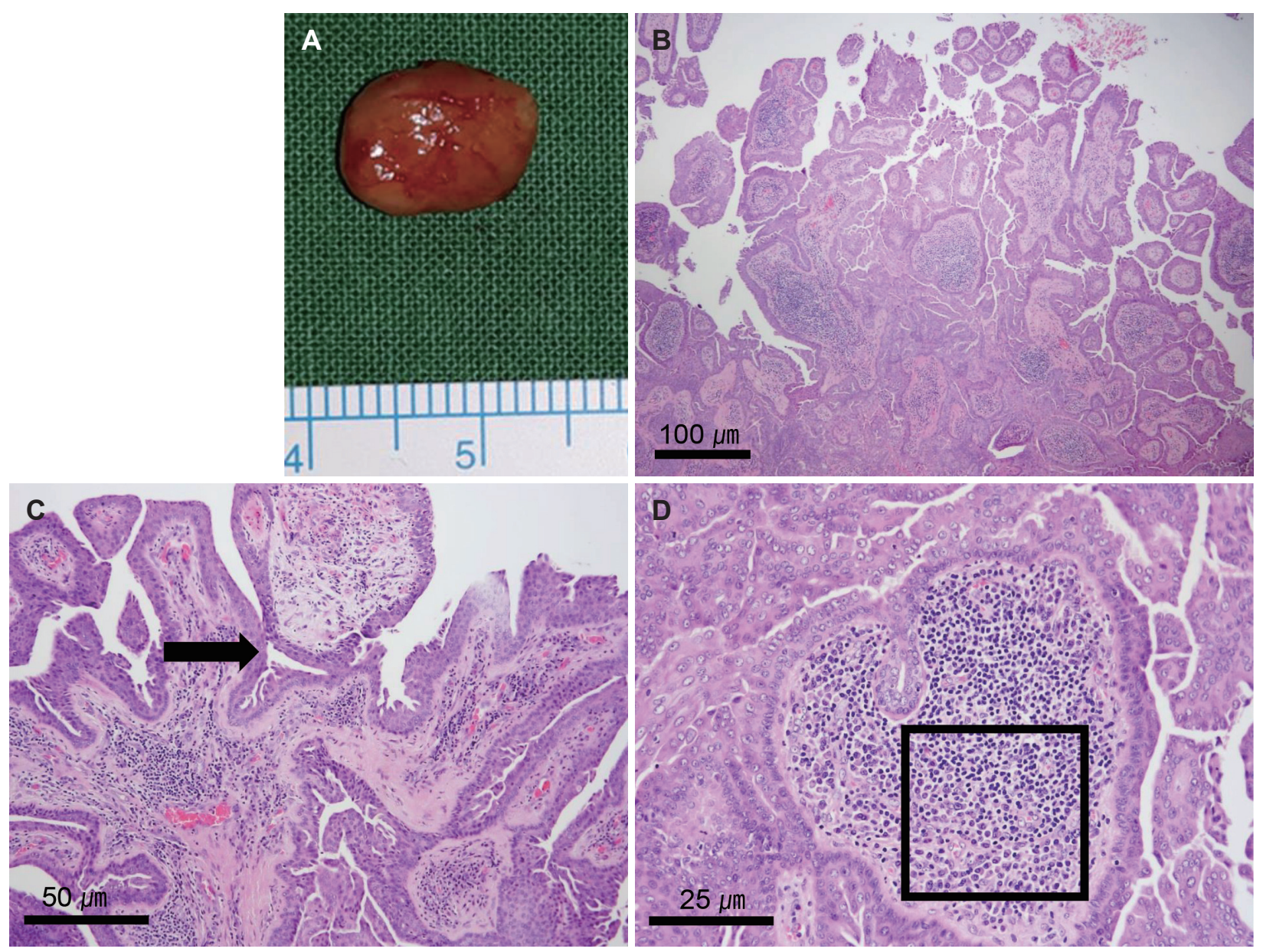

Fig. 2. Gross and microscopic findings of the specimen. The removed mass is yellowish polypoid mass measuring $1.2 \times 0.9 \times 0.6 \mathrm{~cm}(\mathrm{~A})$. Histopathologically, the lesion has numerous papillary projections (H\&E stain, $\times 40)(B)$. The papillary projections are lined by two or more rows of apocrine epithelium (arrow, H\&E stain, $\times 100)(C)$. Dense plasma cell infiltrate is observed in the core of papillary stroma (square, H\&E stain, $\times 200)(D)$. H\&E: hematoxylin and eosin.

indroma), TAA, 아포크린선모반, SCAP, 섬유선종 등이 있 으며 이들은 두피, 사지에 주로 발생한다. ${ }^{3,4)}$

$\mathrm{SCAP}$ 가 외이도에 발생할 경우 증상은 종양으로 인한 외 이도 폐색의 정도에 따라 전도성 난청, 이충만감이 발생할 수 있으며, 이통, 이루, 경미한 출혈을 동반할 수 있다. ${ }^{7)} \mathrm{SCAP}$ 의 조직 소견은 과각화성 상피가 유두상 돌기 모양을 가지며 진 피 방향으로 함입되는 것이 특징적이고, 이 함입의 심부에 위 치한 관 모양의 구조물과 직접 연결된다. ${ }^{5)}$ 유두상 돌기는 내 부에 호산구성 세포질을 풍부하게 가진 원주형 상피와 상대 적으로 세포질이 적은 입방형 상피가 이중으로 덮여 있으며, 간질 부위에 형질세포와 림프구의 빽빽한 침윤이 관찰된다.' CT와 자기공명영상(MRI)이 외이도 종물을 진단하기 위해 중 요하나, 일반적으로 CT를 통하여 병변의 위치, 주변조직과의 관계를 파악할 수 있다. ${ }^{5,8)}$ Kamakura 등 ${ }^{9}$ 은 MRI에서 SCAP 의 특징으로 $\mathrm{T} 1, \mathrm{~T} 2$ 강조 영상에서 중간 정도의 신호 강도를 보이고 $\mathrm{T} 1$ 강조 영상에서 조영제에 약한 조영증강을 보인다
고 기술하였다. SCAP의 낮은 유병률과 비특이적인 증상으로 인해 반드시 악성신생물을 감별진단으로 고려해야 하며, 그 외 이구선 기원의 다른 양성 종물 및 외이도의 진주종, 진주 종성 중이염, 결핵성 중이염 등과도 감별해야 한다. ${ }^{7)}$ 본 증례 의 경우 수술 전 절개생검상 양성종양으로 판단되었고, CT상 외이도 골벽 등의 주위조직에 침윤이 없음이 확인되어 $\mathrm{MRI}$ 촬영없이 국소마취하에 완전절제를 시행했다.

외이도에 발생한 SCAP는 Müller와 Theissig ${ }^{10)}$ 이 11예를 보고한 이후로, 국외에서 7예 정도 보고되었으며, 1,7-9,11-13) 이들 중 TAA와 병발한 1예, ${ }^{11)}$ lipomatous tubular adenoma와 병 발한 1예, ${ }^{12)} \mathrm{SCAP}$ 에서 ductal cancer이 발생한 경우 1 예 ${ }^{13)}$ 외 에는 SCAP만 발생한 증례였다. 사지 및 두부에서 발생하는 $\mathrm{SCAP}$ 의 33\%는 피지선 모반과 동반되어 나타날 수 있으나, ${ }^{14)}$ 외이도에 발생한 SCAP는 본 증례를 포함한 국내외 6예 ${ }^{4-6}$, ${ }^{8,12,13)}$ 에서 피지선 모반을 동반하지 않았으며, 4예, ${ }^{1,7,11)}$ 에서는 피지선 모반의 여부는 기술되지 않았다. 국내에서는 SCAP와 
TAA가 병발한 3예 보고되었으며, ${ }^{4-6)}$ TAA 단독으로 발생한 1 예 ${ }^{15)}$ 가 보고되나, 외이도에 단독으로 발생한 SCAP는 없었다.

$\mathrm{TAA}$ 는 아포크린선 분화를 보이는 진피 내 한선종양으로, 유두상 표피증식과 림프구나 형질세포의 침윤이 없으며 표 피와 연결되지 않고 진피 내에 고립되어 존재하는 경우 진단 된다. ${ }^{15)} \mathrm{SCAP}$ 와 $\mathrm{TAA}$ 의 관계에 대해서는 논쟁의 여지가 있 다. SCAP와 TAA가 병발하는 경우 표면에는 두 층의 선상피 로 둘러싸인 유두종성 낭상함입을 보이며, 기질에는 형질세 포, 림프세포, 중성구들이 침윤된 소견을 보이면서 하부에는 진피 내의 관상구조의 증식을 보이고 관강내로 유두양 돌출 과 단두양 분비(decapitation secretion)를 보인다.) 본 증례에 서는 표면에서 유두종성 낭상함입, 기질에서 형질세포, 중성 구들의 침윤소견은 있으나, 하부에서는 진피 내 관상구조의 증식 및 관강 내로 유두양 돌출, 단두양 분비를 보이는 소견 은 보이지 않아 SCAP로만 진단하였다.

치료는 외과적으로 완전하게 절제하는 것이 가장 좋은 것 으로 알려져 있으며 CT에서 외이도 골부 및 골 파괴 소견이 없다면, 경외이도 절제술, 후이개 절개술 등을 이용하여 완전 절제가 필요하다. ${ }^{78)}$ 완전절제 시에 재발이 드물고, 추가적인 방사선 치료 등은 필요하지 않은 것으로 알려져 있으나, 재발 확인을 위해 주기적인 경과 관찰이 권고된다. ${ }^{7)}$ 본 증례에서는 외이도에 피지선 모반을 동반하지 않으며 조직학적으로 TAA 없이 SCAP만 관찰되는 1예를 진단하였기에 문헌 고찰과 함 께 보고하는 바이다.

\section{Acknowledgments}

None.

\section{Author Contribution}

Conceptualization: Kyung Wook Heo. Data curation: Sung Yool Park, Junhyuk Jang, Ha Young Park. Formal analysis: Junhyuk Jang. Investigation: Junhyuk Jang, Sung Yool Park. Methodology: Kyung Wook Heo, Junhyuk Jang, Ha Young Park. Project administration: Kyung Wook Heo. Resources: Kyung Wook Heo, Junhyuk Jang, Ha Young Park. Supervision: Kyung Wook Heo. Validation: Sung Yool Park, Kyung Wook Heo. Visualization: Kyung Wook Heo. Writing — original draft: Junhyuk Jang. Writing-review \& editing: Kyung Wook Heo.

\section{ORCIDs}

Kyung Wook Heo https://orcid.org/0000-0002-4729-0135
Junhyuk Jang

Sung Yool Park

https://orcid.org/0000-0001-5264-069X

https://orcid.org/0000-0002-5961-3165

\section{REFERENCES}

1) Bruschini L, Ciabotti A, De Vito A, Forli F, Cambi C, Ciancia EM, et al. Syringocystadenoma papilliferum of the external auditory canal. Am J Case Rep 2017;18:520-4.

2) Fletcher CDM. Ear. In: Barnes L, Eveson JW, Reichart P, Sidransky D, editors. Pathology and genetics of head and neck tumors. Lyon, France: IARC;2005. p.330-3.

3) McCalmont TH. A call for logic in the classification of adnexal neoplasms. Am J Dermatopathol 1996;18(2):111.

4) Kang MS, Lim JS, Park SY, Eom MS. Tubular apocrine adenoma with syringocystadenoma papilliferum of the external auditory canal. Korean J Otorhinolaryngol-Head Neck Surg 2012;55(8):51820.

5) Seo JY, Lee YJ, Choi HS, Lee MK. A case of tubular apocrine adenoma with syringocystadenoma papilliferum of external auditory canal removed by postauricular approach. Korean J Otorhinolaryngol-Head Neck Surg 2013;56(4):229-32.

6) Lee CK, Jang KT, Cho YS. Tubular apocrine adenoma with syringocystadenoma papilliferum arising from the external auditory canal. J Laryngol Otol 2005;119(12):1004-6.

7) Guerra-Jiménez G, González Aguado R, Arenas Rodríguez A, Ramos Macías Á. Syringocystadenoma papilliferum of the external auditory canal. Case report and literature review. Acta Otorrinolaringol Esp 2017;68(4):235-7.

8) Arechvo A, Balseris S, Neverauskiene L, Arechvo I. Syringocystadenoma papilliferum of the bony external auditory canal: A rare tumor in a rare location. Case Rep Otolaryngol 2013; 2013:541679.

9) Kamakura T, Horii A, Mishiro Y, Takashima S, Kubo T. Magnetic resonance imaging of syringocystadenoma papilliferum of the external auditory canal. Auris Nasus Larynx 2006;33(1):53-6.

10) Müller R, Theissig F. Syringocystadenoma papilliferum of the outer ear canal. Laryngorhinootologie 1995;74(1):43-5.

11) Kuczkowski J, Izycka-Swieszewska E, Plichta $€$, Cieszyńska J. Combined tumor of ceruminous gland origin in the external auditory canal--a histopathological and immunohistochemical study. Otolaryngol Pol 2010;64(6):385-7.

12) Su TC, Shen KH, Wang HK, Chu PY, Chen ML. Lipomatous apocrine adenoma with syringocystadenoma papilliferum arising from the external auditory canal. Head Neck Oncol 2011;3:36.

13) Diaz RC, Babu SC. Ductal carcinoma arising from syringocystadenoma papilliferum in the external auditory canal. Otol Neurotol 2007;28(6):873-4.

14) Monticciolo NL, Schmidt JD, Morgan MB. Verrucous carcinoma arising within syringocystadenoma papilliferum. Ann Clin Lab Sci 2002;32(4):434-7.

15) Kim HY, Ahn SK, Hur DG, Ko GH. A case of tubular adenoma in the external auditory canal. Korean J Otorhinolaryngol-Head Neck Surg 2013;56(2):95-7. 